\title{
Energy and mass changes of the Eurasian permafrost regions by multi-satellite and in-situ measurements
}

\author{
Reginald R. Muskett", Vladimir E. Romanovsky \\ Geophysical Institute, University of Alaska Fairbanks, Alaska, USA; 'Corresponding Author: rmuskett@gi.alaska.edu
}

Received 13 September 2011, revised 12 October 2011; accepted 30 October 2011.

\begin{abstract}
We investigate changes in total water equivalent mass, land-surface temperature and atmospheric $\mathrm{CO}_{2}$ by satellite-based measurements from August 2002 through December 2008. Our region of interest spans $75^{\circ}$ to $165^{\circ} \mathrm{E}$ and $50^{\circ}$ to $80^{\circ} \mathrm{N}$ centered on the Lena River watershed as a physical reference frame. We find energy and mass changes on the continuous and discontinuous permafrost zones indicating: 1) Arctic uplands such as the Siberian Plateau show strongly positive water equivalent mass and strongly negative land-surface temperature gradients during May months. 2) Arctic lowlands such as the thaw-lake regions of Kolyma, Lena Delta, and Taymyr show strongly negative water equivalent mass and strongly positive land-surface temperature gradients during September months. 3) Areas with strongly positive water equivalent mass and negative land-surface temperature gradients during May months have weakly positive $\mathrm{CO}_{2}$ gradients 4) Areas with strongly negative water equivalent mass and strongly positive land-surface temperature gradients during September months have strongly positive $\mathrm{CO}_{2}$ gradients. This indicates that continuous and discontinuous permafrost ecosystem responses are correlated in phase with energy and mass changes over the period. The Laptev and East Siberia Sea have increasing trends of $\mathrm{CO}_{2}$ atmosphere concentration $2.23 \pm 0.15 \mathrm{ppm} / \mathrm{yr}$ and $2.40 \pm 0.21 \mathrm{ppm} / \mathrm{yr}$, respectively. Increasing trends and strong positive gradients of $\mathrm{CO}_{2}$ atmosphere concentration during Aprils-Mays are evidence that the Arctic Ocean is a strong emitter of $\mathrm{CO}_{2}$ during springtime lead formation. We hypnotize that the increasing $\mathrm{CO}_{2}$ from land and ocean regions is from permafrost thawing and degradation and ecosystem microbial activity.
\end{abstract}

Keywords: Permafrost; GRACE; MODIS; AIRS

\section{INTRODUCTION}

Land- and ocean-surfaces form a fundamental physical boundary of the Earth [1]. Land-surface temperature is a key variable of this physical boundary where thermodynamic and biophysical processes interact at local and regional scales that influence changes of the Earth's climate system [2,3]. Drivers of the Earth's climate system include obliquity, eccentricity, precession, variations of solar radiation and plate tectonics on long time scale [2].

Shorter-term drivers at centennial, decadal and interannual scales are the focus of many investigations [2]. Processes acting on decadal and interannual scale include energy and water cycles, soil-atmosphere micrometeorology, evaporation, evapotranspiration, cloudiness, aerosol chemistry, albedo and ecosystem vitality and phenology [4]. In the terrestrial northern high latitudes land-surface temperature changes form the connecting parameter for warming and degradation of permafrost, development and expansion of taliks, and the mobility and exchange of groundwater that are driven by climate change [5-7].

Our region of interest is the northern high-latitudes with attention to the ecosystems, permafrost zones, watersheds and wetlands from $50^{\circ}$ to $80^{\circ} \mathrm{N}$ and $75^{\circ}$ to $165^{\circ} \mathrm{E}$, Figure 1. Within this region the Lena River and neighboring watersheds provide a physical reference frame to evaluate energy and mass transfers. The Lena is the east most of the three great Siberia rivers with the Yenisei and $\mathrm{Ob}$ '. The continuous permafrost zone mostly underlies the Lena and Yenisei River watersheds. The discontinuous zone underlies their upper-southern parts at the latitude of Lake Baikal (Lena). The central and northern parts of the region are well noted for permafrost wetlands and thaw-lakes in central Yakutia, Taymyr Peninsula and Kolyma River areas. It is one of the regions of the thick sub-surface ice- and carbon-rich deposits known as Yedoma.

Our recent investigations of the northern hemisphere permafrost watersheds have revealed diversity of the 
character of water mass changes [6,7]. The eastern Siberia watersheds show increasing runoff and groundwater storage while regionally averaged winter snow-load shows no trend. In western North America the Mackenzie River and Yukon River watersheds, mostly underlain by the discontinuous permafrost zone show no trend in runoff, yet show trends of decreasing groundwater storage and increasing regionally averaged winter snow-load. These changes in water loads continue from the period of 2002 through 2008.

Using measurements from a multi-satellite sensor suite we will frame our investigation toward surface energy and mass transfers. This will aid investigations of energy balance on Earth's land-surfaces and physical processes which draw from the balance and feedbacks, both negative and positive, with drivers of solar energy input and its feedbacks with atmosphere and vegetation and anthropogenic modification.

The thermal state of the land-surface is the boundary condition for changes of active layer, permafrost and talik that are coupled with climate changes [5]. Water is a fundamental substance on Earth which through its heat capacity can re-distribute energy through the atmosphere and ocean, on the land-surface and within the sub-surface [2]. Recent studies have brought to light that the carbon storage of Earth's permafrost zones exceeds by twice the troposphere load [8]. Thermokarst and permafrost degradation processes associated with thaw-lakes in the permafrost zones have been identified as emitters of methane [9]. Carbon storage is vulnerable to changes in ecosystem, hydrogeology, and land-surface characteristics from climate change [10]. Our investigation seeks to elucidate the coupling of land-surface temperature with near-surface water and atmospheric $\mathrm{CO}_{2}$ mass changes relative to permafrost and terrain setting.

\section{SOURCE DATA}

Our source data for changes of surface energy and mass come from 1) the Moderate Resolution Imaging Spectroradiometer (MODIS) on NASA-Terra satellite daily land-surface temperature, 2) the Gravity Recovery and Climate Experiment (GRACE) mission for water equivalent mass and 3) the Atmospheric InfraRed Sounder (AIRS) (includes the Atmospheric Microwave Sounding Unit) onboard NASA-Aqua for tropospheric $\mathrm{CO}_{2}$. Our source topography data including river and lake elevation is the ESA funded Altimetry Corrected Elevation version 2 Digital Elevation Model (ACE2 DEM) [11]. This model is derived from the Shuttle Radar Topography Mission DEM (finished) and ESA multimission satellite radar altimetry (ESA ERS-1\&2 and Envisat) [12]. We use the 15-degree tiles, 3-arc second posting, reference in the EGM96 WGS84 system, con- sistent with the International Terrestrial Reference Frame 2005 .

\subsection{Modis}

We re-project the grid to be consistent with the international terrestrial reference frame of the GRACE data. Land-surface temperature in Kelvin is derived by algorithm using clear-sky day/night thermal emission and emissivity in the 10.78 to $11.28 \mu \mathrm{m}$ and 11.77 to 12.27 $\mu \mathrm{m}$ bands. Input data derive from the L1B Level 2 swath product using cloud-cover detection routines with corrections for atmosphere column water vapor and boundary level temperatures and off-zenith-angle pointing [13]. We use only those temperatures with the highest quality flag. The accuracy of the MODIS land-surface temperatures is at 1-Kelvin [14,15]. Trends of MODIS (Aqua and Terra sensors) land-surface temperatures show high correlations with near-ground derived air temperatures and sub-surface derived $(3$ to $5 \mathrm{~cm})$ soil temperatures [16].

\subsection{Grace}

The joint US-German (National Aeronautics and Space Administration-Deutsches GeoForschungsZentrum) Gravity Recovery and Climate Experiment provide nominal-monthly near-surface water equivalent mass changes [17]. The tandem satellites measure variations in gravity/mass through changes of the inter-satellite range and range rate from an initial orbit altitude of 485 kilometers, in a controlled free-fall (down to about 200 $\mathrm{km}$ ) non-repeating ground track mode. The mass changes

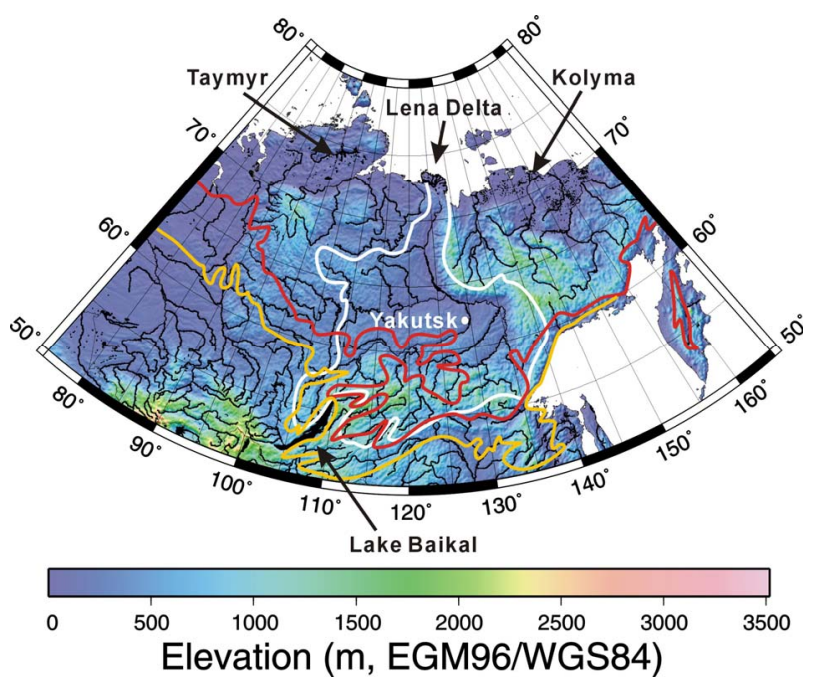

Figure 1. Eurasia centered on the Lena River watershed (white line extent). Permafrost zones are represented by extent lines: the continuous zone (red) and the combined discontinuous and sporadic zones (yellow). Permafrost thaw-lake regions of Kolyma, Lena Delta and Taymyr are identified. 
are coupled to high accuracy onboard GPS and startracking instruments to reference them to the International Terrestrial Reference Frame 2005.

Data for water equivalent mass change comes from Release-04 (R4) Level-3 products provided by the GRACE Science Team centers. Grids are produced at 1-arc-degree global coverage complete to degree and order 40 . The GRACE solution to the gravity potential formulated as an equivalent water mass change (length scale) is given by

$$
\Delta h(\phi, \lambda, t)=\rho \sum_{l=0}^{40} \sum_{m=0}^{l} \frac{(2 l+1)}{1+k_{l}} W_{l} P_{l m} \sin (\phi) \Delta f_{l m}
$$

with

$$
\begin{gathered}
\rho=\frac{a_{e} \rho_{e}}{3 \rho_{w}} \\
W_{l}=\exp \left[\frac{\left(l r / a_{e}\right)^{2}}{4 \ln (2)}\right] \\
\Delta f_{l m}=\Delta C_{l m}(t) \cos (m \lambda)+\Delta S_{l m}(t) \sin (m \lambda)
\end{gathered}
$$

and coefficients $P_{l m}$ : Normalized Legendre polynomials, $\Delta C_{l m}(t)$, and $\Delta S_{l m}(t)$ : Normalized time-varying Stokes spherical harmonic geopotential coefficients, $a_{e}$-Earth mean radius, $r$-spatial radius, $k_{l}$-Love numbers, $\rho_{e}$ Earth mean density, $\rho_{w}$-water density, $t$ - time, and $\phi, \lambda$ are latitude and longitude [17]. Beyond degree (order) 40 to 70 , the inherent noise level in the mass change signal becomes significant [18]. Processing includes downward propagation and adjustments to remove the time-variable mass change effects from tides and atmosphere and mean variation (GRACE geoid model). A normalized Gaussian smoother filter mitigates striping artifacts produced by the orbit non-crossing and control-descent geometry [17,18]. Differences in processing (de-aliasing) and error sources and products are attributable to differences in assumed zero-degree and order Stokes harmonics, tide (liquid and solid) models and the modeled atmosphere mass change removal, respectively in decreasing order of magnitude [19,20].

GRACE global coverage in our investigation is from August 2002 through December 2008. Glacial isostatic adjustment (GIA) is a global phenomenon by way of mantle flow following the decay of the Pleistocene ice sheets in North America and Euro-Scandinavia [21]. We remove modeled GIA from the GRACE grids [22].

\subsection{Airs}

$\mathrm{CO}_{2}$ free-troposphere measurements (concentration in parts per million) derive from the Atmospheric InfraRed Sounder onboard the NASA-Aqua $[23,24]$. The Level 3 data are in the form of monthly near-global grids, $60^{\circ} \mathrm{S}$ to $90^{\circ} \mathrm{N}$, from October 2002. Grid spacing is 2 degrees latitude by 2.5 degrees longitude. Daytime and nighttime $\mathrm{CO}_{2}$ concentrations are derived from a suite of spectral channels with $15 \mu \mathrm{m}$ bandwidth and peak sensitivities at about $450 \mathrm{hPa}$ with accuracy better than 2 parts per million [25]. Validations have been accomplished using ground-based upward viewing spectroradiometers, aircraft-based spectro-radiometers, model simulations and with other satellite sensor comparisons [24,25]. AIRS has proven capability to measure both mid-troposphere transport and surface sources of $\mathrm{CO}_{2}$ of natural and anthropogenic origin $[25,26]$.

The time series data from satellite-derived snow water equivalent and in-situ gauge station runoff are explained in Muskett and Romanoky [5,6]. We introduce a new time series of bias-corrected gauge precipitation from Yang et al. [27]. Corrections to the precipitation data include trace events, losses from wetting and evaporation, and wind induced errors (under catch) using a common reference gauge (World Meteorological Organization) from more than 350 stations in our region of interest Figure 1 and the Lena and Yenisei River watersheds which average 290. The Yang et al. [27] data set spans 1973 through 2004. We utilize data from August 1998 through December 2004

\section{METHODOLODY}

Our mathematical basis derives from Linear \& NonLinear Algebras of Hilbert Space applied to the Generalized Inverse and Potential Theory [28]. We use this methodology to derive regional trends, gradients, error estimates and statistical significance drawing from other works of applied statistics theory [29,30].

On the MODIS, GRACE and AIRS datasets we apply the Sandwell biharmonic method with Greens Functions zero-curvature constraint to produce global grids at 0.2-degree (about 22-km) spatial resolution [31,32]. This method is useful for MODIS products to mitigate cloudvoids. The MODIS grids remain at daily temporal resolution and the GRACE and AIRS grids remain at monthly temporal resolution. Statistical evaluation tests are performed to monitor validity of the resultant grids.

The Sandwell biharmonic method was first applied to derive detailed and accurate geoid maps from GOES-3 and SEASAT altimetry data by mitigation of the error sources [31,32]. Reference [33] extended this method to include a tension parameter to suppress spline overshoots in areas of sharp gradients and [34] made further refinements to generalize the technique to other geophysical applications. Tests of this method on MODIS MOD11A1 daily 1-km land-surface temperature data on Eurasia, Figure 2 and Table 1, show satisfactory results with 
P-values better than the level of 0.05 (95\% significant). Figure 2 top plots show the change in land-surface temperatures, daily $1-\mathrm{km}$ resolution, from 1 to 31 May 2008 (Figure 2) and from 1 to 30 September 2008 (Figure 2). The gray-regions are cloud-voids, i.e. no data. Figure 2 bottom plots show the results of filling the cloud-void regions by the Sandwell biharmonic method.

\section{RESULTS AND DSCUSSION}

\subsection{Timeseries}

Our ongoing investigation builds on research applying methods of satellite geodesy to issues of water equivalent storage changes and their sources in the permafrost watersheds of the northern hemisphere [6,7]. Monthly time series of regionalized water equivalent mass chan-

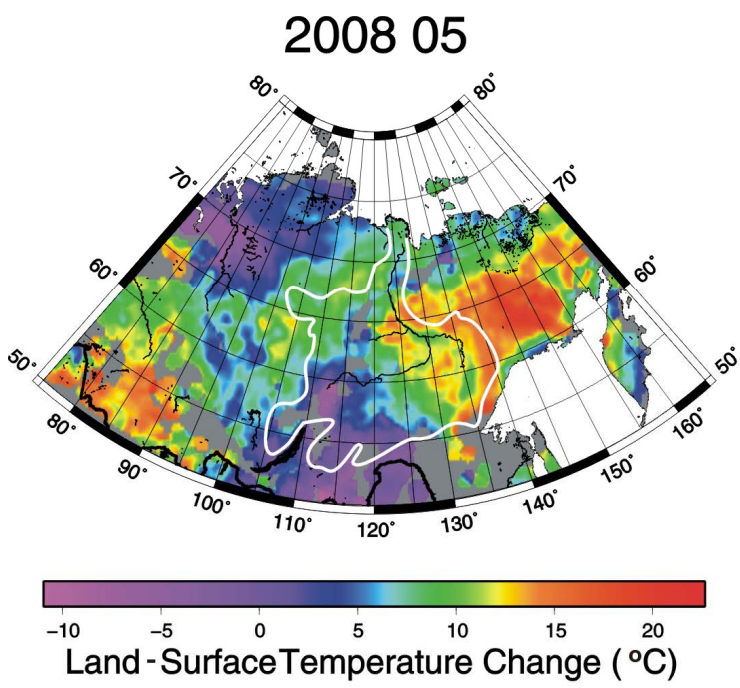

200805

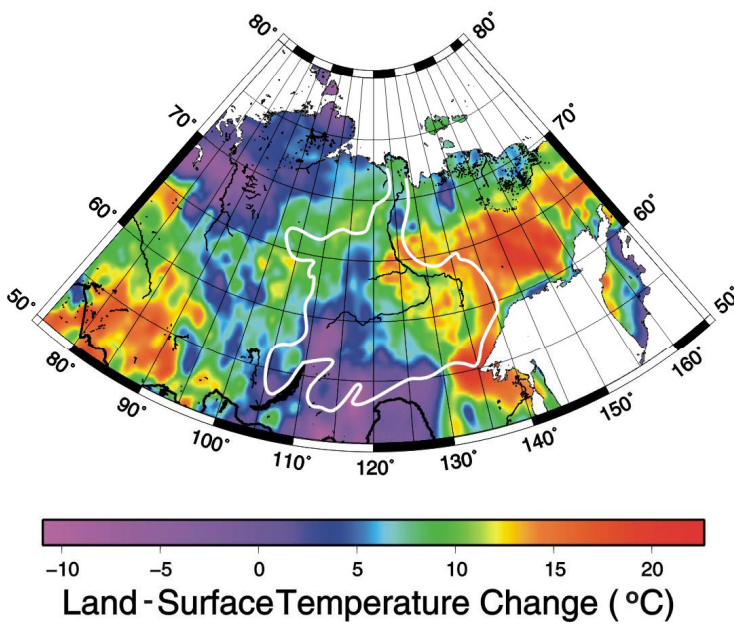

ges and least squares trends are illustrated in Figure 3. GRACE (Figure 3(A)) exhibits total water equivalent storage change from surface and sub-surface sources in the Lena and Yenisei River watershed regions. Least squares trends (black lines) whose p-values correspond to significance at $95 \%$ illustrate the seasonal extremes during Mays (water mass loading) and Septembers (water mass unloading). These parallel the least squares trend over all months (gold). All indicate substantially

Table 1. Comparison of MOD11A1 derived mean temperature changes before and after interpolation with the Sandwell biharmonic method.

\begin{tabular}{ccc}
\hline & May 2008 & September 2008 \\
\hline Original & $+7.98^{\circ} \mathrm{C} \pm 4.90^{\circ} \mathrm{C}$ & $-5.63^{\circ} \mathrm{C} \pm 3.80^{\circ} \mathrm{C}$ \\
Interpolation & $+7.46^{\circ} \mathrm{C} \pm 5.75^{\circ} \mathrm{C}$ & $-5.69^{\circ} \mathrm{C} \pm 4.59^{\circ} \mathrm{C}$ \\
\hline
\end{tabular}

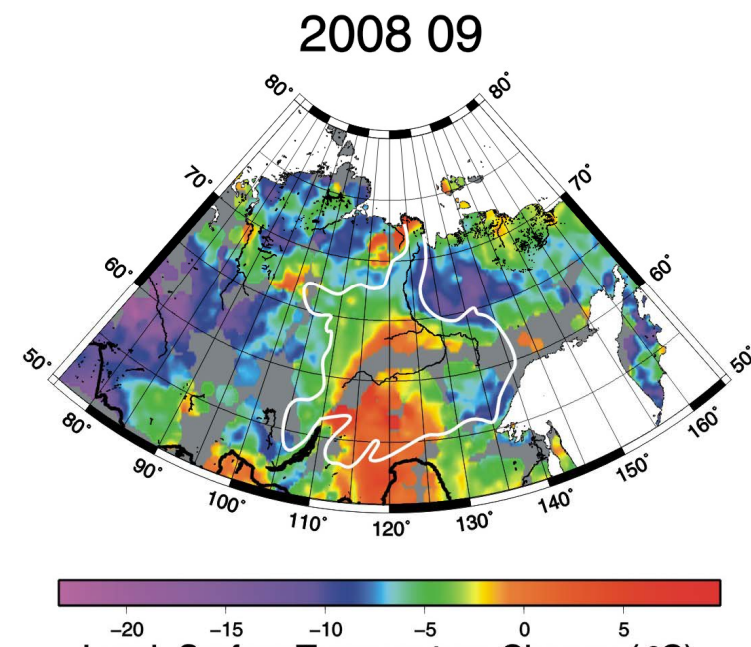

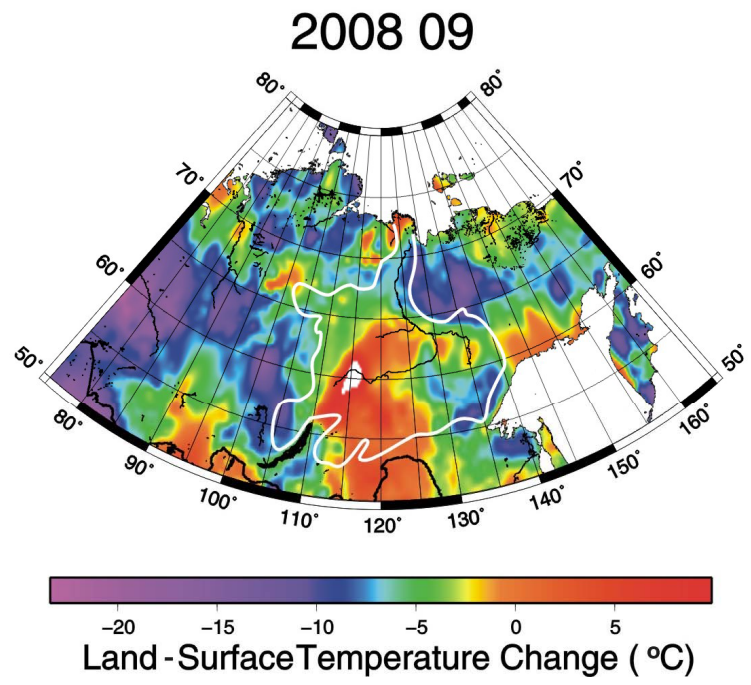

Figure 2. Land-surface temperature changes during May 2008 and September 2008. Top plots show cloud-void areas (grey) and bottom plots show cloud-oids filled by Sandwell biharmonic spline interpolation method. 
increasing water equivalent storage [6]. Figure 3(B) illustrates winter snow mass loading as measured by the Special Scanning Microwave/Imager and the Advanced Microwave Sensing Radiometer sensors, top, and areaaveraged runoff (from ground stations), below. The pattern of runoff (particular the springtime water mass unloading) is distinctive of high-latitude watersheds with the maximum runoff occurring in June [6,7]. During the winter months base flow from groundwater discharge is increasing as well as the spring flows $[35,36]$. While yearly runoff is strongly increasing, winter snow loads show no trend on the largest Siberian watersheds of the continuous permafrost zone of Eurasia. Using techniques of signal reduction we find that ground water storage significantly increasing [11]. Regionalized vegetation and shallow $(\sim 1$ to $2 \mathrm{~cm})$ soil moisture monthly series derived from AMSR-E are shown in Figure 3(C). The time series show only small seasonal-latitudinal variations without trend [11]. Figure 3(D) re-plots 3(B) this time with summertime bias-corrected precipitation from the Lena and Yenisei River watersheds and the entire region (Figure 1). The period of the gauge stations is from 1998 through 2004. The trends are very weak with high uncertainty and very low significance. The strongly increasing trends of total water storage and runoff changes have very low correlation to precipitation trends. The source is other than precipitation.

\subsection{Speciotemporal Gradient Fields}

Figure 4 (left) shows the gradient fields of water equivalent mass (A GRACE), land-surface temperature (B MODIS) and atmospheric $\mathrm{CO}_{2}$ changes (C AIRS) during May and September from 2002 through 2008. Figure 4 (center) shows our error estimates (uncertainties) Root Mean Square (RMS) deviation levels of the gradient fields. Figure 4 (right) shows the significance level fields of the gradient fields. RMS is typically about $30 \%$ and less of the strongest gradients with significance up to and above $95 \%$. Weak gradients near zero magnitude do no rise about their RMS values and have low significance.
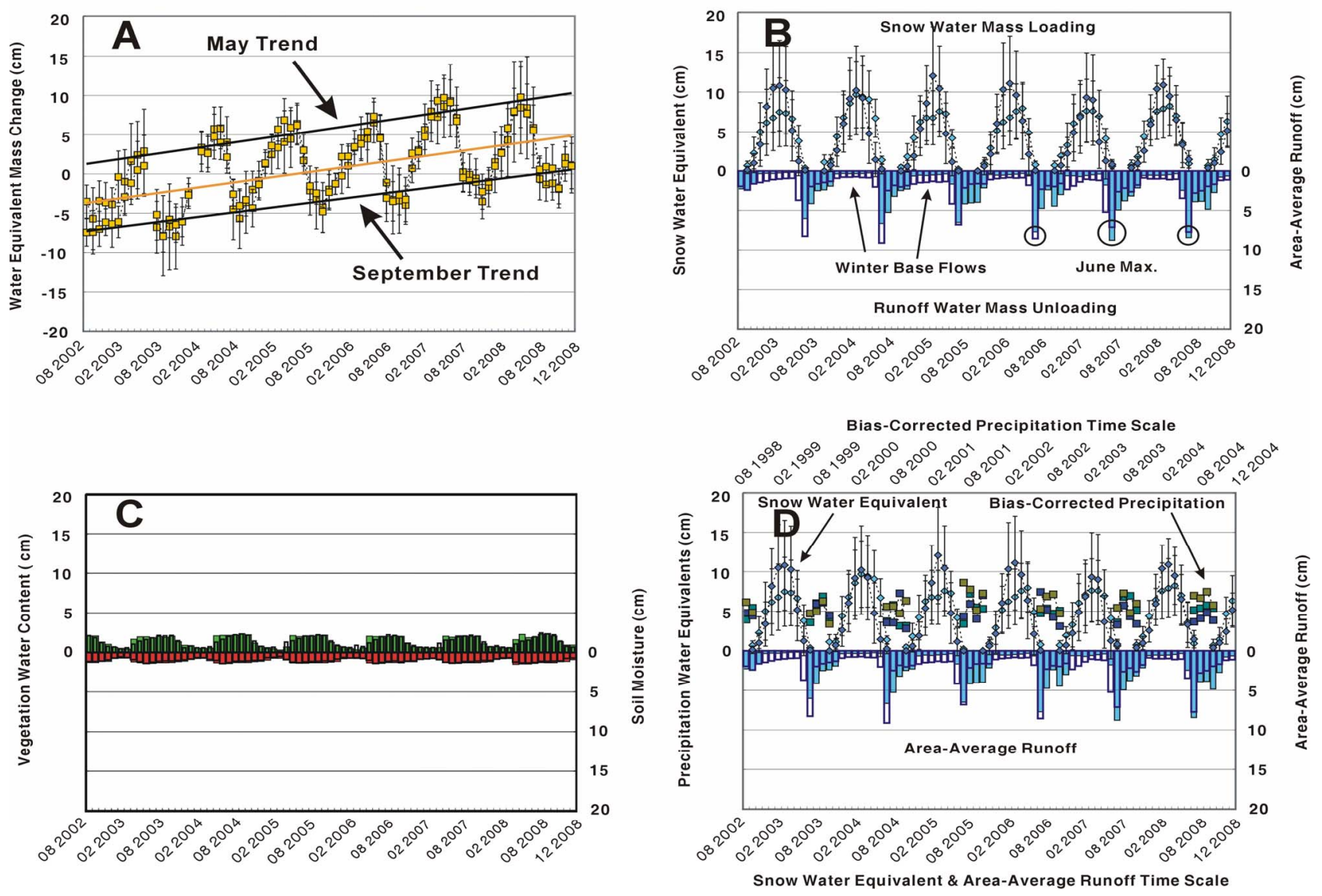

Figure 3. Regionalized time series of water mass changes in the Lena and Yenisei River watersheds. (A) GRACE water equivalent mass series and least squares trends, (B) SSM/I-AMSR-E snow water equivalent series (top) area-average runoff (below), (C) AMSR-E vegetation water content series (top) and soil moisture (below), (D) same as B with summertime bias-corrected precipitation series. 


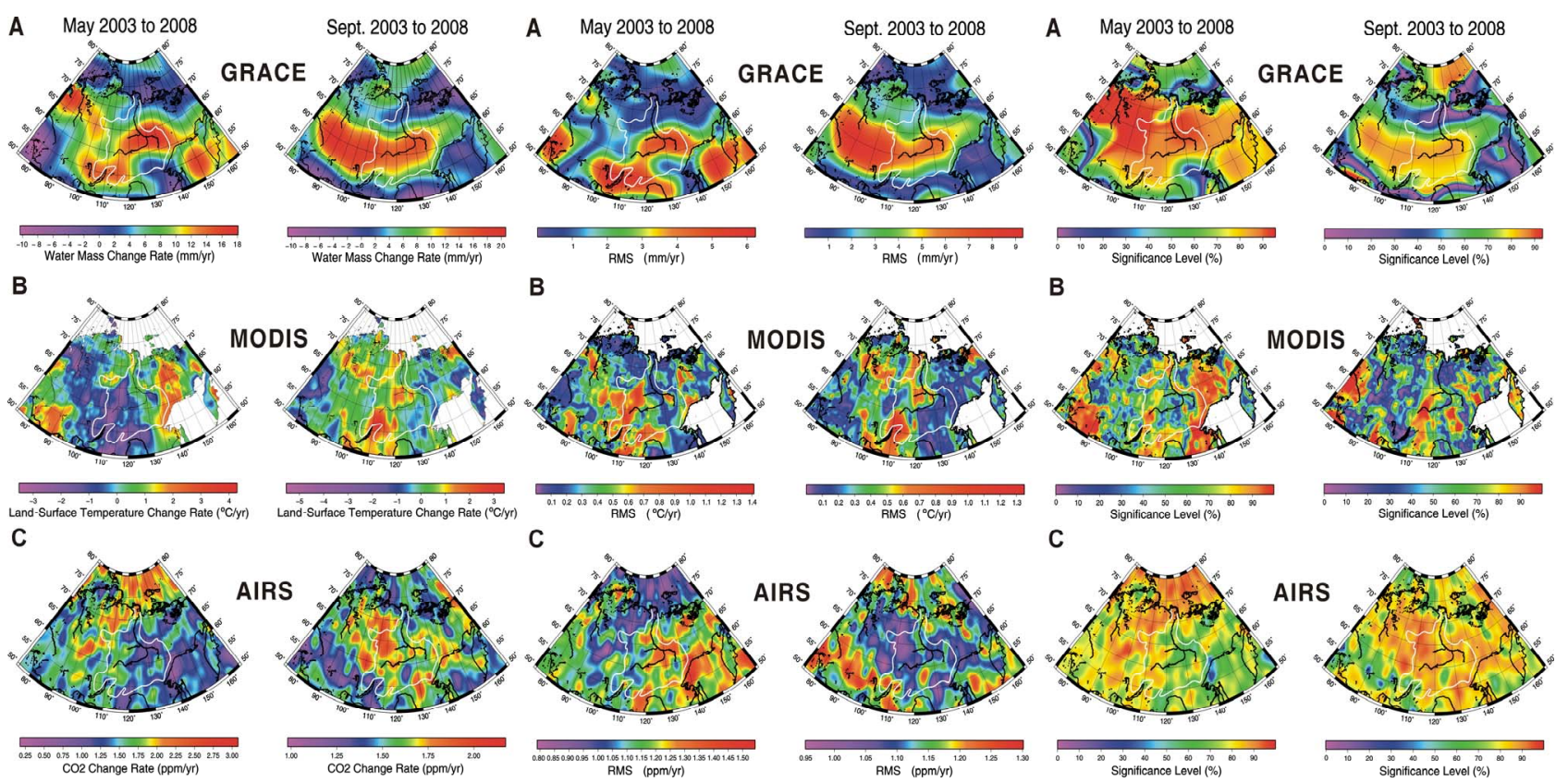

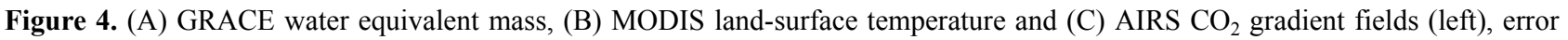
estimates by Root Mean Squares (RMS, center) and significance levels (right).

The gradient fields indicate coupled ecosystem-energy-water response to forcing and feedback over the period of measurement. Results from the gradient fields are summarized:

1) Arctic uplands such as the Siberian Plateau show strongly positive water equivalent mass and strongly negative land-surface temperature gradients during May months.

2) Arctic lowlands such as the thaw-lake regions of Kolyma, Lena Delta, and Taymyr show strongly negative water equivalent mass and strongly positive landsurface temperature gradients during September months.

3) Areas with strongly positive water equivalent mass and negative land-surface temperature gradients during May months have weakly positive $\mathrm{CO}_{2}$ gradients.

4) Areas with strongly negative water equivalent mass and strongly positive land-surface temperature gradients during September months have strongly positive $\mathrm{CO}_{2}$ gradients.

This indicates permafrost ecosystem microbial response that is correlated and in phase with energy and mass changes over the period of measurements. Multiregression of in-situ measurements on the Arctic Indigirka lowland floodplain indicate the role of methanogens increasing the methane flux in addition to water table and active layer thickness changes over time [37]. GRACE positive gradients are in particularly strong on the central and southern Lena continuous and discontinuous permafrost zone during Mays and Septembers. On the northern Yenisei River watershed continuous permafrost zone west side of the Lena, GRACE positive gradients are strong during Mays. During Septembers the center and southern Yenisei River watershed continuous and discontinuous zones shows strongly positive gradients while the northern part becomes weakly positive.

Lowland regions in the continuous permafrost zone with abundant thermokarst-lakes such as the Taymyr, Lena Delta, and Kolyma regions have strong negative water equivalent mass-positive $\mathrm{CO}_{2}$ gradients during Septembers. These regions are noteworthy for their $\mathrm{CH}_{4}$ emissions [9]. $\mathrm{CO}_{2}$ and $\mathrm{CH}_{4}$ emissions are in part driven by lake expansion by shoreline erosion and limited by lake drainage through lakebed talik that are linked to permafrost degradation [38].

Strongly positive $\mathrm{CO}_{2}$ gradients on the Siberian coastal seas of the Arctic Ocean in May 2003 through 2008 are shown in Figures 4(C). Analysis of the Arctic Ocean daily sea-ice area time series indicates harmonics associated with short-to-intermediate temporal physical processes [39]. Analysis of AIRS time series indicates the Arctic Ocean is a strong emitter of $\mathrm{CO}_{2}$ in Aprils and Mays from 2003 through 2008, Figure 5. The Laptev and East Siberia Sea least squares trends are $+2.23 \pm$ $0.15 \mathrm{ppm} / \mathrm{yr}$ (99\% significance) and $+2.40 \pm 0.21$ $\mathrm{ppm} / \mathrm{yr}$ (99\% significance). The detrend-series (Figures 5(B) and (D)) shows the punctuated response of $\mathrm{CO}_{2}$ release in April-May months. Springtime lead formation is a contributor to strong water vapor emissions [40]. This gives evidence that a wintertime build-up of $\mathrm{CO}_{2}$ in the water beneath pack ice is then emitted during the 

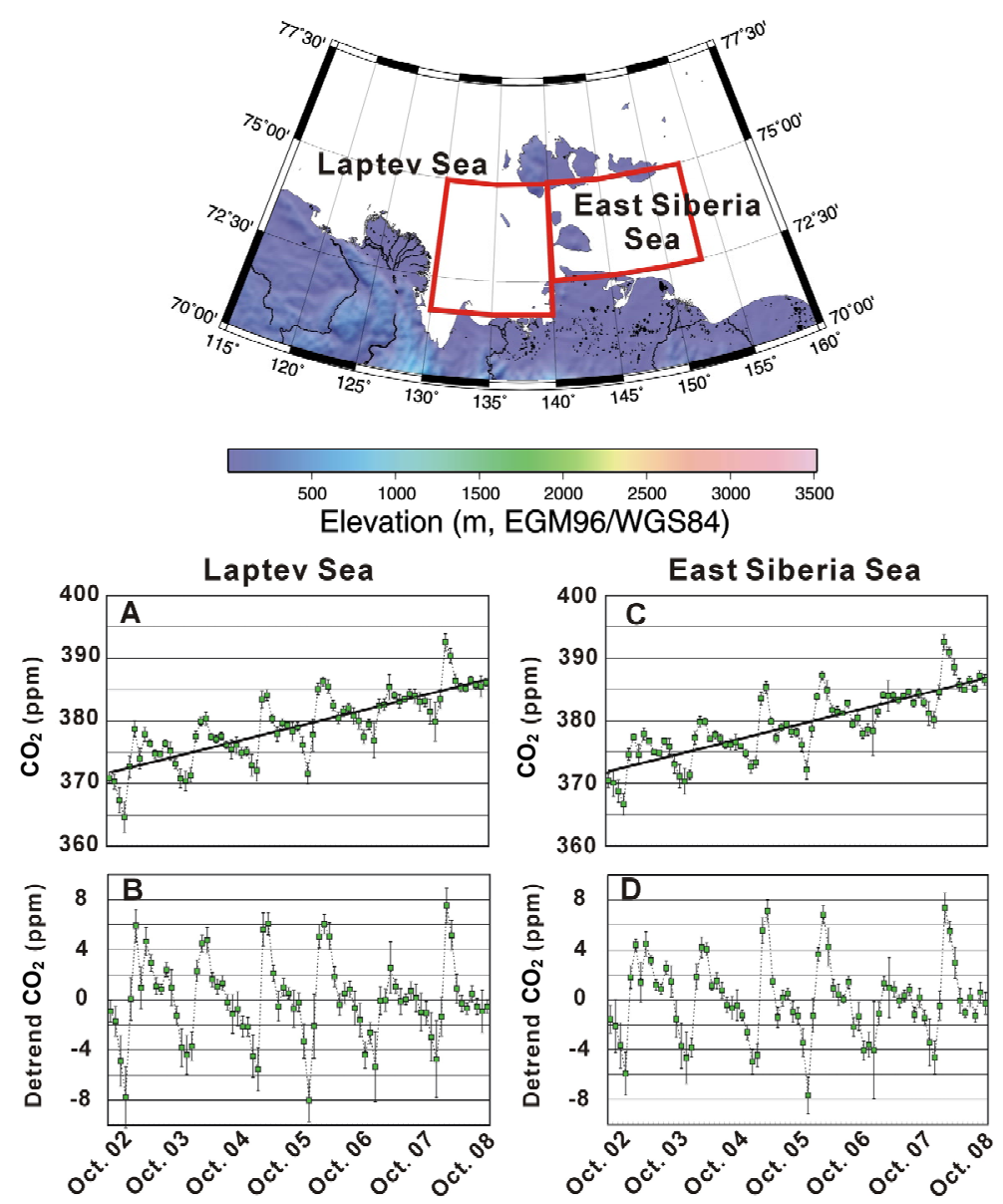

Figure 5. AIRS $\mathrm{CO}_{2}$ time series and least squares trends. $B$ and $D$ show the detrended series.

springtime lead openings. We hypothesize that the source of increases in $\mathrm{CO}_{2}$ beneath the wintertime pack ice may in part from sub-ice algae, seabed methanogens and unstable permafrost [41].

Our investigations of the Arctic permafrost watersheds point to the strong role of groundwater storage changes $[6,7]$. Permafrost regions can contain liquid water and in large quantities [42]. The increasing groundwater storage of the Eurasian Arctic watersheds and the decreasing groundwater storage of the western North American Arctic watersheds is not simply linked to water volume changes. Rather, as permafrost thaws and degrades to talik internal flow paths can form and those existing can become connected. In the continuous and discontinuous permafrost zones there are regions of increasing capacity and residence time that can be a function of new closed talik as well as regions of decreasing residence time that can be a function of new through talik. In the western North American Yukon River watershed the latter is the case whereas in the Arctic Costal Plain of Alaska, the former is the case, on average. Our measurements indicate that the observations of increasing number of thaw lakes in the continuous permafrost zones are not simply linked to precipitation increases [43] and decreasing number of thaw lakes in the discontinuous permafrost zone that are linked to sub-surface drainage [44] are manifestations of the changing groundwater mass storage and residence times.

Land and seabed permafrost are vulnerable to climatedriven forcing affects and feedbacks [10,45]. These include changes in ecosystem, organic-mineral soil composition, thermal profile and water content. In particular for permafrost there are strong increasing gradients in equivalent water mass transfers on the discontinuous zone of the Lena region during May and September months, indicating high potential of thawing and degradation. During Septembers there are strong decreasing gradients in water equivalent mass and strong increasing gradients in $\mathrm{CO}_{2}$ changes on the Taymyr, Lena Delta and Kolyma regions (thaw-lakes) of the continuous zone, potentially signaling permafrost thawing and degradation and increasing carbon release.

Current estimates of the global $\mathrm{CH}_{4}$ emission budget points to the Arctic wetlands contributing up to $12 \%$ [46]. 
Arctic methanogenesis is keyed to thaw lake thermokarst and permafrost degradation processes [38]. We hypothesize that increasing numbers of thaw lakes by permafrost thawing and degradation in the continuous permafrost zones will likely be a strong positive feedback in increasing $\mathrm{CH}_{4}$ emissions driven by climate warming that can offset the negative feedback of decreasing numbers of thaw lakes and reducing $\mathrm{CH}_{4}$ emissions in the discontinuous zone on an area average basis $[44,46]$.

\section{CONCLUSIONS}

In this paper we present results from an investigation of multi-satellite sensors for measurements of near-surface energy and mass exchanges relative to land-surfaces of the northern hemisphere with a focus on the northeastern Eurasian permafrost watersheds. The results of our investigation are:

1) Arctic uplands such as the Siberian Plateau show strongly positive water equivalent mass and strongly negative land-surface temperature gradients during May months.

2) Arctic lowlands such as the thaw-lake regions of Kolyma, Lena Delta, and Taymyr show strongly negative water equivalent mass and strongly positive landsurface temperature gradients during September months.

3) Areas with strongly positive water equivalent mass and negative land-surface temperature gradients during May months have weakly positive $\mathrm{CO}_{2}$ gradients.

4) Areas with strongly negative water equivalent mass and strongly positive land-surface temperature gradients during September months have strongly positive $\mathrm{CO}_{2}$ gradients.

This indicates permafrost ecosystem (microbial) response that is correlated and in phase with energy and mass changes over the period of measurements.

Increasing trends of $\mathrm{CO}_{2}$ atmosphere concentration over the Laptev and East Siberia Sea and strong gradients during Aprils-Mays from 2002 through 2008 are evidence that the Arctic Ocean is a strong emitter of $\mathrm{CO}_{2}$ during springtime lead formation. We hypnotize permafrost thawing and degradation and ecosystem microbial activity are drivers of the $\mathrm{CO}_{2}$ changes.

\section{ACKNOWLEDGEMENTS}

This work was funded through supporting grants from NASA (NNOG6M48G), the National Science Foundation (NSF) ARC0632400, ARC-0612533, and ARC0856864 projects, Alaska EPSCoR NSF award \#EPS-0701898 and the State of Alaska. The Alaska Region Supercomputing Center is thanked for computing facilities support. NASA and Deutsches GeoForschungsZentrum are thanked for the GRACE data. NASA Goddard Space Flight Center and the Jet Propulsion Laboratory, Cal. Inst. of Technology are thanked for MODIS and
AIRS data, respectively. Daqing Yang, University of Alaska Fairbanks is thanked for the northern hemisphere bias-corrected precipitation data. The Generic Mapping Tools were used in this research.

\section{REFERENCES}

[1] Saltzman, B. (1983) The theory of climate. Advances in geophysics 25. Academic Press, New York.

[2] Flanner, M.G., Shell, K.M., Barlage, M., Perovich, D.K. and Tschudi, M.A. (2011) Radiative forcing and albedo feedback from the Northern Hemisphere cryosphere between 1979 and 2008. Nature Geoscience, 4, 151-155. doi:10.1038/ngeo1062

[3] Kleidon, A. (2008) Entropy production by evapotranspiration and its geographic variation. Soil \& Water Ressources, 3, S89-S94.

[4] Zhang, X., Friedl, A.M., Schaaf, B.C. and Strahler, A.H. (2004) Climate controls on vegetation phenological patterns in northern mid- and high latitudes inferred from MODIS data. Global Change Biology, 10, 1133-1145. doi:10.1111/j.1529-8817.2003.00784.x

[5] Romanovsky, V.E., Drozdov, D.S., Oberman, N.G. Malkova, G.V., Kholodov, A.L., Marchenko, S.S., Moskalenko, N.G., Sergeev, D.O., Ukraintseva, N.G., Abramov, A.A., Gilichinsky, D.A. and Vasiliev, A.A. (2010) Thermal state of permafrost in Russia. Permafrost \& Periglacial Processes, 21, 136-155. doi:10.1002/ppp.683

[6] Muskett, R.R. and Romanovsky, V.E. (2009) Groundwater storage changes in arctic permafrost watersheds from GRACE and in situ measurements. Environmental Research Letters, 4.

[7] Muskett, R.R. and Romanovsky, V.E. (2011) Alaskan permafrost groundwater storage changes derived from GRACE and ground measurements. Remote Sensing Journal, 3, 378-397. doi:10.3390/rs3020378

[8] Schuur, E.A.G., Vogel, J.G., Crummer, K.G., Lee, H.L. James, O., Sickman, J.O. and Osterkamp, T.E. (2009) The effect of permafrost thaw on old carbon release and net carbon exchange from tundra. Nature, 459, 556-560. doi:10.1038/nature08031

[9] Walter, K.M., Edwards, M.E., Grosse, G., Zimov, S.A. and Chapin III, F.S. (2007) Thermokarst lakes as a source of atmospheric $\mathrm{CH}_{4}$ during the last deglaciation. Science, 318, 633-636. doi:10.1126/science. 1142924

[10] Grosse, G., Marchenko, S., Romanovsky, V., Wickland, K.P., French, N., Waldrop, M., Bourgeau-Chavez, L., Striegl, R., Harden, J., Turetsky, M., McGuire, A.D., Camill, P., Tarnocai, C., Frolking, S., Schuur, E. and Jorgenson, T. (2011) Vulnerability of high latitude soil organic carbon in North America to disturbance. Journal Geophysical Research, 116, G00K06. doi:10.1029/2010JG001507

[11] Berry, P.A.M., Smith, R.G., Freeman, J.A. and Benveniste, J. (2008) Towards a new global digital elevation model. In: Sideris, M.G., Ed., Observing Our Changing Earth, 133, Part 2, International Association of Geodesy Symposia 2008, Springer-Verlag, Berlin,

[12] Smith, R.G., Berry, P.A.M. and Benveniste, J. (2007) Representation of rivers and lakes within the forthcoming ACE2 Global Digital Elevation Model. In: ESA 2nd Space for Hydrology Workshop, Geneva, 12-14 Novem- 
ber 2007.

[13] Wan, Z. (2008) New refinements and validation of MODIS land-surface temperature/emissivity products. Remote Sensing Environment, 112, 59-74. doi:10.1016/j.rse.2006.06.026

[14] Coll, C., Wan, Z. and Galve, G.M. (2009) Temperaturebased and radiance-based validations of the V5 MODIS land surface temperature product. Journal Geophysical Research, 114, D20102. doi:10.1029/2009JD012038

[15] Wang, W., Liang, S. and Meyers, T. (2008) Validating MODIS land surface temperature products using longterm nighttime ground measurements. Remote Sensing Environment, 112, 623-635. doi:10.1016/j.rse.2007.05.024

[16] Hachem, S., Duguay, C.R. and Allard, M. (2011) Comparison of MODIS-derived land surface temperatures with near-surface soil and air temperature measurements in the continuous permafrost terrain. The Cryosphere Discussions, 5, 1583-1625. doi:10.5194/tcd-5-1583-2011

[17] Wahr, J., Molenaar, M. and Bryan, F. (1998) Time variability of the Earth's gravity field: Hydrologic and oceanic effects and their possible detection using GRACE. Journal Geophysical Research, 103, 30205-30229. doi:10.1029/98JB02844

[18] Tapley, B.D., Bettadpur, S., Watkins, M. and Reigber, C. (2004) The gravity recovery and climate experiment: Mission overview and early results. Geophysical Research Letters, 31, L09607. doi:10.1029/2004GL019920

[19] Quinn, K.J. and Ponte, R.M. (2010) Uncertainty in ocean mass trends from GRACE. Geophysics Journal International, 181, 762-768.

[20] Zenner, L., Gruber, T., Jäggi, A. and Beutler, G. (2010) Propagation of atmospheric model errors to gravity potential harmonics-Impact on GRACE de-aliasing. Geophysics Journal International, 182, 797-807. doi:10.1111/j.1365-246X.2010.04669.x

[21] Peltier, W.R. (2004) Global glacial isostasy and the surface of the Ice-Age Earth: The ICE-5G (VM2) model and GRACE. Annual Reviews Earth \& Planetary Science, 32, 111-149. doi:10.1146/annurev.earth.32.082503.144359

[22] Paulson, A., Zhong, S. and Wahr, J. (2007) Inference of mantle viscosity from GRACE and relative sea level data. Geophysics. Journal International, 171, 497-508. doi:10.1111/j.1365-246X.2007.03556.x

[23] Barkley, M.P., Monks, P.S. and Engelen, R.J. (2006) Comparison of SCIAMACHY and AIRS C02 measurements over North America during the summer and autumn of 2003. Geophysical Research Letters, 33, L20805. doi:10.1029/2006GL026807

[24] Xiong, X., Barnet, C., Maddy, E., Sweeney, C., Liu, X., Zhou, L. and Goldberg, M. (2008) Characterization and validation of methane products from the Atmospheric Infrared Sounder (AIRS). Journal Geophysical Research, 113, G00A01. doi:10.1029/2007JG000500

[25] Chahine, M., Chen, L., Dimotakis, P., Jiang, X., Li, Q.B., Olsen, E., Pagano, T., Randerson, J. and Yung, Y. (2008) Satellite remote sounding of middle tropospheric $\mathrm{CO}_{2}$. Geophysical Research Letters, 35, L17807. doi:10.1029/2008GL035022
[26] Neelin, J.D., Lintner, B.R., Tian, B., Li, Q., Zhang, L., Patra, P.K., Chahine, M.T. and Stechmann, S.N. (2010) Long tails in deep columns of natural and anthropogenic tropospheric tracers. Geophysical Research Letters, 37, L05804. doi:10.1029/2009GL041726

[27] Yang, D.Q., Kane, D., Zhang, Z., Legates, D. and Goodison, B. (2005) Bias-corrections of long-term (1973-2004) daily precipitation data over the northern regions. Geophysical Research Letters, 32, L19501. doi:10.1029/2005GL024057

[28] Scales, J.A., Smith, M.L. and Treitel, S. (2001) Introductory inverse theory. Samizdat Press, Golden.

[29] Brockwell P.J. and Davis, R.A. (1991) Time series: Theory and methods. 2nd Edition, Springer-Verlag, New York. doi:10.1007/978-1-4419-0320-4

[30] Wackernagel, H. (2003) Multivariate geostatistics: An Introduction with Applications. 3rd Edition, Springer, New York.

[31] Sandwell, D. T. (1987) Biharmonic spline interpotation of GOES-3 and SEASAT altimeter data. Geophysical Research Letters, 14, 139-142. doi:10.1029/GL014i002p00139

[32] Sandwell, D.T. and Smith, W.H.F. (2009) Global marine gravity from retracked Geosat and ERS-1 altimetry: Ridge segmentation versus spreading rate. Journal Geophysical Research, 114, B01411. doi:10.1029/2008JB006008

[33] Wessel, P. and Bercovici, D. (1998) Interpolation with splines in tension: A Green's function approach. Mathematical Geology, 30, 77-93. doi:10.1023/A:1021713421882

[34] Wessel, P. (2009) A general-purpose Green's functionbased interpolator. Computers \& Geoscience, 35, 1247 1254. doi:10.1016/j.cageo.2008.08.012

[35] Yang, D., Kane, D., Hinzman, L.D., Zhang, X., Zhang T. and Ye, H. (2002) Siberian Lena River hydrologic regime and recent changes. Journal Geophysical Research, 107, 4694. doi:10.1029/2002JD002542

[36] Yang, D.Q., Ye, B.S. and Shiklomanov, A. (2004) Stream flow changes over Siberian Yenisei River Basin. Journal Hydrology, 296, 59-80. doi:10.1016/j.jhydrol.2004.03.017

[37] Van Huissteden, J., Maximov, T.C. and Dolman, A.J. (2011) High methane flux from an arctic floodplain (Indigirka lowlands, Eastern Siberia). Journal Geophysical Research, 110, G02002.

[38] Van Huissteden, J., Berrittella, C., Parmentier, F.J.W., Mi, Y., Maximov, T.C. and Dolman, A.J. (2011) Methane emissions from permafrost thaw lakes limited by lake drainage. Nature Climate Change, 1, 119-123. doi:10.1038/nclimate1101

[39] Muskett, R.R. (2011) Non-stationary drivers of polar sea ice area. Natural Science, 3, 351-368. doi:10.4236/ns.2011.35047

[40] Anders, E.L., Guest, P.S., Persson, P.O.G., Fairall, C.W., Horst, T.W., Moritz, R.E. and Semmer, S.R. (2002) Near-surface water vapor over polar sea ice is always near ice saturation. Journal Geophysical Research, 107, 8033. doi:10.1029/2000JC000411

[41] Shakhova, N., Semiltov, I., Salyuk, A., Yusupov, V., Cosmach, D. and Gustafsson, Ö. (2009) Extensive methane venting to the atmosphere from sediments of the 
East Siberian Arctic shelf. Science, 327, 1246-1250. doi:10.1126/science.1182221

[42] Kalabin, A.I. (1973) Scientific-procedural principles of investigation and the main features of the hydrogeology of northern countries (exemplified by northeastern USSR). In: Sanger, F.J. and Hyde, P.J., Eds., USSR Contribution-Permafrost, 2nd International Conference, National Academy of Sciences, Washington, 13-28 July 1973.

[43] Smith, L.C., Sheng, Y., MacDonald, G.M. and Hinzman, L.D. (2005) Disappearing ARCTIC LAkes. Science, $\mathbf{3 0 8}$, 1429. doi:10.1126/science. 1108142

[44] Yoshikawa, K. and Hinzeman, L.D. (2003) Shrinking thermokarst ponds and groundwater dynamics in discon- tinuous permafrost near Council, Alaska. Permafrost \& Periglacial Processess, 14, 151-160.

doi:10.1002/ppp.451

[45] Jorgenson, MT., Romanovsky, V., Harden, J., Shur, Y., O'Donnell, J., Shuur, E.A.G., Kaneveskiy, M. and Marchenko, S. (2010) Resilience and vulnerability of permafrost to climate change. Canadian Journal Forestry Research, 40, 1219-1236. doi:10.1139/X10-060

[46] Bloom, A.A., Palmer, P.L., Fraser, A., Reay, D.S. and Frankerberg, C. (2010) Large-scale controls of mathanogenesis inferred from methane and gravity data. Science, 327, 322-325. doi:10.1126/science. 1175176 